\title{
IBN GABIROL'S RELIGIOUS POETRY AND SUFI POETRY
}

RAYMOND P. SCHEINDLIN

The Jewish Theological Seminary of America

I.

It is well established that the startling innovations introduced into Hebrew poetry by poets in the circle of Hasdai Ibn Shaprut in tenthcentury al-Andalus were due to the influence of Arabic poetry and society. In the tenth century the influence of Arabic extended mainly to secular Hebrew poetry, the very existence of this poetry being one of the most interesting of the innovations. Liturgical poetry also changed, but not as radically; until Solomon Ibn Gabirol ( $c a$ 1021-ca 1058). Early Andalusian Hebrew liturgical poetry can be understood as a simple evolutionary development of the liturgical poetry of ninth and tenth century Iraq.

With Ibn Gabirol, however, the Andalusian liturgy acquires new characteristic forms, expressing new themes, in many cases even serving new liturgical functions and occupying new liturgical sites '.

It has long been recognized that the Hebrew liturgical poets employed motifs from secular Arabic love poetry. Israel Levin has attempted to explain the introduction of such motifs and a number of other distinctive features of Golden Age religious poetry as the result of the influence of Arabic Sufi poetry ${ }^{2}$. There is nothing

1 The word "site" refers to the points in the liturgy that were customarily embellished by poetry. The worshiper who speaks in these prayers is of course the precentor in a public synagogue service. Though he speaks in the first person singular, it is the worship of a community that he expresses. The intimate tone of these poems has deceived many into thinking of these poems as private meditations. The truth is that, as in love poetry, they embody a dialectic between private and public expression. This subject is dealt with in R. P. Scheindurn, The Gazelle: Medieval Hebrew Poems on God, Israel, and the Soul, Philadelphia 1991.

${ }^{2}$ His studies on this subject are collected in I. LEvin, Hasód wěhayěsód, Lydda 1986, pp. 92-136. But the idea was expressed tentatively already in his article on Ibn Gabirol in the Ensiglopedya 'ibrit, Jerusalem - Tel Aviv 1955-1956, X, cols. 218-230, and definitely in the version of that article' that appeared in the Encyclopaedia Judaica, Jerusalem 1971, VII, col. 237. 
religiously impossible about this hypothesis. Late twelfth and early thirteenth century Jews like Abraham Maimuni admired certain aspects of Sufism, adapted them to Judaism, and even incorporated quotations from classic Sufi texts into their own writings. Already in eleventh century Spain, the influence of mild Sufi pietism on Bahya Ibn Paquda is well established 3. Levin's hypothesis would push back the influence of Sufi texts on Jewish writers by half a century, also not an impossibility. But how is such an hypothesis to be proved? Granted that Levin is able to point to some poems by Solomon Ibn Gabirol that use phrases reminiscent of phrases in early Sufi poets, do such reminiscences justify us in making the leap from noting the parallels to positing influence? Implicitly Levin's hypothesis raises the question of just what is meant by literary influence.

In order to take Levin's hypothesis to the next step and to deal with the questions just raised, we would need to study the poetry of Sufi masters that was available for the Hebrew poets to read and be impressed by. But Sufi poetry predating the thirteenth century has received rather little attention, overshadowed as it is by the more flamboyant and abundant poetry of Ibn al-Fārid, Ibn 'Arabì, alŠuštarì, and their successors in Arabic and Persian ${ }^{4}$. Yet even before the age of these luminaries poetry was hardly lacking among

${ }^{3}$ G. D. COHEN, "The Soteriology of R. Abraham Maimuni», PAAJR 35 (1967) 7598; 36 (1968) 33-56; G. VAJDA, La théologie ascétique de Bahya Ibn Paquda, Paris 1947. For the chain of reasoning that places the period of Bahya's activity in the third quarter of the eleventh century, see B. Safran, "Bahya Ibn Paquda's Attitude toward the Courtier Class", in I. TwERSKy (ed.), Studies in Medieval Jewish History and Literature, Cambridge, Mass. 1979, 154-196.

${ }^{4}$ It was still possible for S. M. STERN to say, in his Hispano-Arabic Strophic Poetry, Oxford 1974, pp. 82-83, that Sufi poetry only arose in the twelfth century. Early Sufi poetry tends to be overlooked by specialists in Arabic poetry also because it is not in the mainstream of classical poetry and does not appear in adab works. Thus F. Gabrieli, "Religious Poetry in Early Islam", in G. E. von Grunebaum (ed.), Arabic Poetry: Theory and Development, Wiesbaden 1973, 6-17 found religious poetry in early Islam only in Kharijite verse, and thereafter only in Abū-l-'Atāhiya. He had, however, given a lecture, "Problemi e forme della poesia mistica musulmana", published in Convegno di scienze morali, storiche, e filologiche, Rome 1956, 35-49 in which he makes mention of the earlier poets. There is a penetrating but all-too-brief notice in R. JACOBI, "Arabische Dichtung (8-13. Jahrhundert)" in H. GÄTJE (ed.), Grundriss der arabischen Philologie, Wiesbaden 1982, II, 46-49. The only other studies known to me are the very general treatments by A. SCHIMMEL, As Through a Veil: Mystical Poetry in Islam, New York 1982, pp. 11-48; M. LINGs, "Mystical Poetry", in J. Ashtiany et al. (eds.), ‘Abbasid Belles-Lettres, Cambridge 1990. 
the Sufis. In order to study the ways in which Sufi poetry could have influenced the Hebrew poets of eleventh and twelfth century al-Andalus, I have surveyed the major Sufi treatises that predate them and have assembled a corpus of the poetry preserved in these texts ${ }^{5}$. I have been studying these poems with a view toward developing criteria that will either validate or invalidate Levin's hypothesis, in the hope that this research may also cast some light on the methodological questions mentioned above.

Levin finds evidence of Sufi influence on Hebrew liturgical poetry both in Sufi poetry on the love of God and in Arabic zuhd poetry, dealing with asceticism and renunciation of the world. We take these up in sequence.

II.

It is commonplace to say that the history of Sufism begins with the introduction of the theme of love of God into Islamic asceticism. This assertion is completely borne out by the use of love poetry in Sufi treatises. Much of the poetry quoted in Sulami's sketches of famous Sufis in his Tabaqāt al-süfīya is simply love poetry; not religious poetry that draws on the conventions of secular love poetry, but love poetry plain and simple, sometimes by known secular poets. The early Sufi masters who used poetry did not necessarily compose it themselves but would recite lines of known secular poems as a kind of prooftext in confirmation of a point of their preaching. Sometimes they would use secular verses for the startling effect of putting them in a religious context. The verse is not always treated allegorically, but is often used as exemplary; for instance, if one who loves flesh and blood can be affected to the degree depicted in the poem, how much more is expected of one who would truly

${ }^{5}$ The treatises from which I have culled the poems are: Abū Naşr 'Abdallah b. 'Alī al-Sarrāŷy (d. 378/988), Kitāb al-luma' edited by R. A. Nicholson, Leiden 1914; Al-Kalabādī (d. 380/990), Kitāb al-ta'arruf li-madhab ahl al-tasawwuf, edited by A. J. ARberRY, Cairo; 1934; Abū Tālib al-Makkī (d. 386/998), Qūt al-qulūb, Cairo, 1310/1893; Sulamì (d. 412/1021), Tabaqāt al-sūfíya, edited by J. PEDERSEN, Leiden 1960; Abū Nu'aim al-Işfahānī (d. 430/1038), Hilyat al-awlīy $\bar{a}$ (partially), Cairo 19331938, 10 vols.; Qusayrī (d. 465/1072), Risäla, Cairo n.d. In addition I have studied the modern dīwāns of al-Hallāŷ, edited by L. MASSIGNON, Paris $1955^{2}$ and by K. Š AYīi, Baghdad 1984, and of al-Šiblī, edited by K. Saybī, Baghdad 1967; and the poems attributed to Rābica, on which see below, notes 27 and 30 . 
love God. Many are the anecdotes in which a master is thrown into religious ecstasy, goes mad, or even dies on hearing someone in the street reciting a secular love poem or recalling a secular verse. The master's behavior on such occasions often recalls the mad behavior related in the Masāric al-cuššă (by Ja'far b. Ahmad al-Sarrāŷy, d. $500 / 1106$ ) of persons especially sensitive to love and love poetry ${ }^{6}$.

The upshot is that we cannot always tell whether a line of poetry in the mouth of a master is of his own composition or not. When, as often, the poem is introduced with the word tamat tala (meaning "to make use of a line of poetry by someone else»), it clearly is by someone else, whether a Sufi or a secular poet. But more often the introductory expression is ansha'a yaqūl ("he recited, saying"), which gives no clue as to whether the master is or is not the author, and therefore whether the poem was composed with religious intent or not. By far the majority of the love poems in Sulami, like the Song of Songs, have no explicit religious theme. In this situation we have to treat every love poem said to have been recited by a Sufi master as a religious poem, whether or not the religious content is manifest.

We now turn to the poems likely to have been composed by the Sufis, as opposed to simply being quoted by them or mentioned in connection with them. They are mostly short, consisting of two to eight lines '. I found it convenient to sort them into broad categories determined by the overall intention of each poem, and to study themes like love in connection with the larger category in which they appear. I found it possible to sort nearly all the poems in my corpus into the following categories: 1 . wisdom-type poems of instruction; 2. theoretical statements about the nature of the mystic's religious experience; 3 . personal statements purporting to describe a particular mystic's religious experience (sometimes shading off into a kind of religious $f a k r)$; 4. prayers. There is some mixing of categories, particularly inasmuch as theoretical poems and poems of personal experience sometimes end with a brief prayer. The famous poem attributed to Rābica, Uhibbuka hubbaini hubba-l-hawà («I love

${ }^{6}$ According to J. N. Bell, "Al-Sarrāj’s Mas̄āric al-‘ushshāg: A Hanbalite Work?», JAOS 99 (1979) 235-248, many of these secular stories were transmitted to Sarrây by a Sufi, demonstrating again the free flow of literary material on secular love into the sphere of Sufism. The very purpose of the Masasiric - secular or religious- is the subject of scholarly debate.

${ }^{7}$ A few are longer, especially in the diwwān of Hallāy, and there is one of heroic length by Yunayd in the Hilyat al-awliy $\bar{a}^{\text {? }}$. 
you with two loves") may be understood as a poem of personal experience, with a certain theoretical tendency.

The wisdom-category is by far the smallest. Perhaps surprisingly, prayer, though larger, is also not a big category, though enough items belong to belong to it to permit some generalizations. Poems describing the nature of the mystical experience, whether theoretical or personal, make up by far the bulk of the material. Zuhd poetry is almost completely lacking ${ }^{8}$. Not all the poems refer to themes of love, but a significant number of them do-perhaps half; most belong to the theoretical or personal categories. In many of the poems, the love element consists in no more than a passing allusion to standard conventions of love poetry. But in other poems love themes are structurally significant. Abū Husayn al-Nūrî, for example, in a personal poem, uses the ideas of keeping the relationship secret and the discreet use of messengers to convey a subtle point about communication between the adept and God ':

I swear I have not confided my secret and his to anyone, for fear our secrets be broadcast. Nor have my eyes gazed at him with a look that let observant eyes ${ }^{10}$ witness our confidence.

All I did was make thought between us go-between, and it delivered what our hearts concealed.

Sarî al-Saqatî uses love themes in a theoretical poem to demonstrate the high standard required of the 'äbid "':

\footnotetext{
${ }^{8}$ It may be of interest to note the almost complete absence of zuhd poems; I have found no more than two or three. This confirms the view that, for all its religious content, zuhd poetry is essentially poetry and belongs to the sphere of adab and conventional piety rather than to that of Sufism. See R. JACOBI, "Arabische Dichtung", p. 46. This distinction is important to our understanding of the relationship of zuhd to Sufism; but it also contributes to the argument below against Levin's claim that Ibn Gabirol's evident borrowings from zuhd poetry demonstrate his closeness to Sufism.

${ }^{9}$ Source: Sarrāŷ, Lumac', pp. 233 and 248.

10 Variant: "hearts".

"Sources: Sarrāŷ, Lumac, p. 251; Qušayri, Risäla, p. 160. The poem is attributed to an unnamed woman who supposedly addressed them to al-'Abbās b. al-Ahnaf, according to the anecdote in the Kităb al-Muwašs by Abū-l-Tayyib Mubammad b. Iş̧ăq al-Wašsă, edited by $R$. BRƯnNow, Leiden 1886. The context, by the way, confirms my interpretation of kawäsiya as meaning "covered with flesh".
} 
When I claimed to love, she said, "You lie! for if so, why do I see your limbs covered [with flesh]?

It's only love when your skin sticks to your gut, when you are too deaf to answer when someone calls, when you wither so that love leaves you nothing but an eye with which to weep or to confide».

Sometimes love themes are used to demonstrate the extent of the Sufi's attachment to God. Themes from love poetry are used to show how the 'ábid is different from other men, set apart from normal society, an object of criticism and scorn. Sometimes this theme shades off into fakr, when the poet boasts of his isolation and the hostility he endures from society. Here is a typical example, by Yaḥyà Ibn Mucād ${ }^{12}$ :

I am dying of an illness, for which my cure is not encountered, nor is there any release from what I experience in my suffering.

They say, "Yahyà has gone mad after having been healthy"; but the blamers do not know what is in my insides.

When a man is sick with love of his master, whom else can he hope to be the doctor for his illness?

With God he passes his time; in pleasure you see him, whether he is obedient or whether he rebels ${ }^{13}$.

Let me and my condition alone! Don't add to my misery!

Let free my reins [to go] toward the Lord of Lords.

$\mathrm{Ah}$, shun me, and desire that I be isolated.

Do not reveal what my heart has hidden.

Entrust me to my Lord and cease blaming me, that I may enjoy the company of my Lord in spite of everything [I feel] inside.

Already from the examples cited above it is clear that suffering plays a large part in the poetry of this corpus. A huge number of individual lines could be culled at random on this theme, lines that describe the 'a $\bar{b}$ bid as dying, as experiencing burning heat and freezing

${ }^{12}$ Sources: Sarrāŷ, Lumá, p. 253; Ișfahānī, Hilyat, X, 62 (lines 1 and 3 only). This theme is a link to Jewish poetry, as we shall see.

${ }^{13}$ The meaning of this verse is unclear to me. 
cold, as weeping uncontrollably, as emaciated, sick, or depressed ${ }^{14}$. Let one short poem by Junaid stand for all ${ }^{15}$ :

My heart is burning; my tears are running; pain is collected in full force; patience strewn.

How can one be sure of an inconstant one in the face of the love, the longing, the anxiety he caused?

O God! If there is anything that can save me, grant it to me, while I have yet a spark of life.

Poems of the theoretical type tell how a lover of God acts and what he feels; poems of personal experience describe how the speaker acts and feels. But in almost all the poems it is the cábid, the worshiper, and his spiritual suffering, not God, who is the center of attention. It is amazing how little of the hymnic strain is heard in this poetry. Most of it seems not to be intended as a vehicle for the adoration of God, but as an exploration of religious virtuosity, sometimes in the form of instruction on how to recognize it, at others as a description of the feelings of those who embody it.

Of the various dominant trends of Abbasid love poetry, it was the ' $u d r \vec{i}$ that attracted the Sufis ${ }^{16}$, precisely because of the centrality in that body of poetry of the experience of frustration and suffering, and because of the preponderance of attention it devotes to the lover's virtuosity as a sufferer. The suffering of the lover who can never be united with his love was perfectly analogous to the suffering of the 'a $\bar{b} b i d$ who longs helplessly for union with God, or for return of the state of ecstacy he has experienced before. Here the early Sufi masters found the human experience that most closely paralleled their religious experience. Not surprisingly we find them often quoting Maŷnūn-Lailà (or poems attributed to him) and Ŷamî-Butayna, and using verses from their poems for their sam $\bar{a}^{\varsigma}$-sessions ${ }^{17}$.

${ }^{14}$ An extremely rare exception: Dū-l-Nūn, Maȳâlu qulūbi 'l-'ārifīna bi-raudatin (Işfahānī, Hilyat, X, 369 and 391, which speaks of fulfillment; but other than the word "love", which occurs a few times in the poem, the imagery comes from outside the sphere of love poetry.

${ }^{15}$ Source: Işfahānī, Hilyat, X, 13.

16 G. E. von Grunebaum, "Avicenna's Risāla $f \tau^{\prime}$ '- $i$ ish $q$ and Courtly Love», JNES 11 (1952) 237.

${ }^{17} \mathrm{~K}$. Saybì has very appropriately appended to his edition of Siblīs dīwān a group of twenty-one poems by others that Sibli is said to have quoted. Of these, five are by Maŷnūn or Ŷamil. 
III.

Just how closely are these sentiments paralleled in Hebrew poetry of the synagogue?

Since Ibn Gabirol was the first of the Hebrew poets to compose liturgical poetry using Arabic prosody, we turn first to him. And in fact there are a number of striking liturgical poems by Ibn Gabirol in which the erotic theme is highly developed. For example ${ }^{18}$ :

Come to me at dawn, my love, and go with me, for my heart thirsts to see my people.

For you I will spread golden beds within my hall,

I'll set my table for you, I'll serve you my own bread.

I'll fill a goblet for you from the clusters of my own vineyards; heartily you'll drink, my love, my food will please you.

I'll take my pleasure with you as I did with my people's prince, the son of your servant Jesse, that Bethlehemite chief.

How similar is this poem to the love poems found in early Sufi treatises?

The fact that this poem (and Ibn Gabirol's other rěšuyôt on the Davidic theme) deals with the religious yearnings of a community rather than of an individual does not in itself argue against a genetic relationship. Synagogue poetry is by definition the prayer of the community. The separated state of lovers in the Song of Songs

18 Source: D. JARDEN, Šîê haqodeš lěrabbî Šelomô ibn Gabîrôl, Jerusalem 19711972, II, p. 460; H. SCHIRMANN, Ha-sìra ha-'ibrît bi-Sĕfarad û-bë-Prôb’ens, JerusalemTel Aviv 1960', I, p. 241; Ibn Gabirol, Selected Religious Poems, edited by I. Davidson, translated by I. Zangwill, Philadelphia 1923, p. 4; K. Dreyer, Die religiöse Gedankenwelt des Salomo Ibn Gabirols, Leipzig 1930, p. 70. N. RoTH, "Sacred' and 'Secular' in the Poetry of Ibn Gabirol", Hebrew Studies 20-21 (19791980) 75-78. For verse translation and further discussion, see R. P. SchEINDLIN, The Gazelle, poem 8. 
regularly served the synagogue poets as a means of describing the exiled condition of the Jewish people and their longing for redemption; in adapting secular love poetry to the synagogue, the Jews, like the Sufis, would merely have been investing its conventions with the new meaning appropriate to their own set of religious problems. The question is, did the Jews adopt elements of secular love poetry in such a way that we have the right to conclude that they learned the technique from the Sufis?

To answer this question, I believe that it is not enough to look for individual pairs of similar phrases. We need to try to understand the character of the religious experience expressed, or rather, embodied in the poem. Individual motifs can crop up in different cultures for a variety of reasons, but evidence of meaningful influence must be sought in a similar mental set, a similar structure of experience that would create a climate favorable to the adoption of materials of one culture by another. The extent to which such similarities exist can often be deduced from the formal and emotional structure of the literary work. In the absence of such larger mental similarities, there would seem to be no way to explain how and why the individual literary motifs would cross the space between the two cultures.

Ibn Gabirol's poem is a fantasy in which Israel, represented as a woman, addresses a silent interlocutor, who may be God or the Messiah. Israel's speech is in effect a seduction. The speaker takes the aggressive role, promising food, wine, and beds, conjuring up an atmosphere of luxury and sensuousness. She alludes to similar rendezvous that she has had with others in the past. There is not the slightest intimation that she fears that this invitation will go unanswered ${ }^{19}$.

The allusion to David at the poem's end intensifies the sensuousness of the atmosphere, for David is one biblical figure whose physical beauty and sexuality are an important part of his story. I think that the depiction of the glorious age of the Davidic monarchy as a lovers' rendezvous is unprecedented in Hebrew poetry. If the poem is addressed to the Messiah (who is to be a descendant of David) instead of God, that too would be without precedent. The

${ }^{19}$ It is interesting to compare Ibn Gabirol's tongue-in-cheek Amnon anî hole $(\mathrm{H}$. Schirmann, Ha-sirâ ha-'ibrit, I, p. 214; R. P. Scheindlin, Wine, Women, and Death: Medieval Hebrew Poems on the Good Life, Philadelphia 1986, p. 110). 
depiction of the theme of Israel's marital union with God in the sanctuary of the Temple does have solid roots in rabbinic lore; but if the intended lover here is God, the poet's comparison of Him to a flesh-and-blood lover like David would also result in a daring heightening of the erotic aspect of this ancient tradition.

Not one of the approximately two hundred Sufi poems in my corpus resembles this one and its fellows in any significant way. The reason is evident. The liturgical purpose of Ibn Gabirol's poem is to express hope for redemption. The speaker is hopeful, even confident, and certainly anything but depressed, as she cites past pleasures as precedent for a delicious future. There is no calling of attention to the speaker's own religious virtuosity; the poem is an ardent speech designed to draw the hesitating lover into the circle of the speaker's own warmth.

It is impossible to imagine that the Sufi poetry known to have existed before Ibn Gabirol could have been the literary source of the imagery, style, or spirit of Ibn Gabirol's Davidic liturgical poems. The only source that we can be sure of is one internal to the Jewish community, that ancient mainstay of Hebrew synagogue poetry, the Song of Songs. Elsewhere I have discussed how Ibn Gabirol developed the images of the Song of Songs by combining them with passages in the stories of the young David ${ }^{20}$. The most that can be said in favor of Arabic influence is the novelty of Ibn Gabirol's using Arabic prosody in a short religious poem on the theme of love, for short Arabic love poems in quantitative meter certainly are typical of the Abbasid period; it may be that that the sensuous associations of secular Arabic love poetry were carried into Hebrew with the form. Furthermore, similar seduction scenes can be found in secular Arabic poetry. But they are decidedly not found in the cudri poetry so dear to the hearts of the early Sufis. For overtly sexual themes in Sufi poetry we have to wait for later centuries. Given the emotional chasm between the sensuousness of Ibn Gabirol's Davidic poems and the chasteness of the prior Sufi poetry, it is impossible to see any direct link between the two. We might even go further and say that it is unlikely that the kind of religious spirit that created Ibn Gabirol's poem was not even capable of being affected by Sufi love poetry, so different in character are

${ }^{20}$ In R. P. SCHEINDLIN, The Gazelle, pp. 90-107. 
the two types of religious yearning that they express. But at this stage it would probably not be prudent to assume this much consistency on the part of any poet. At the very least we can be sure that these poems by Ibn Gabirol are independent of Sufi poetry.

Ibn Gabirol can only have gotten the inspiration for this series of poems from within the Jewish tradition. The liturgical site of the poem required that it deal with the love between God and Israel; the Song of Songs was already a mainstay of such poems. A poet who was so innovative in other ways could very well have had the genius to create these sensuous dialogues on his own, drawing directly on secular Arabic poetic traditions. And although the influence of Arabic writing on Ibn Gabirol's literary production in general is beyond dispute, in the particular case of the these poems Sufi influence is out of the question.

IV.

The themes and the tone of love poetry may be present even in poems in which the language is not so overtly sensuous as in those built around the Davidic theme described above. Yet, while many of these poems speak of the love of God, we do not find a single one that could be characterized as a love poem in the sense of being structured around the theme of love like the Sufi poems quoted earlier. Furthermore, rigorous comparative method would dictate that references to the love of God or even references to secular love motifs are not sufficient to establish a connection between Ibn Gabirol and Sufi poetry; for love of God is a theme of the Psalms, which even more than the Song of Songs was a mainstay of Jewish worship from its earliest beginnings, and secular love poetry was just as available to Ibn Gabirol as it was to the Sufis. To decide for meaningful Sufi influence, we shall have to identify a similarity in the structure of the poems reflecting a similiarity in the structure of the religious mentality that the poems seek to express.

Levin offers five Sufi poems and six Hebrew poems by Ibn Gabirol to demonstrate the probability of Ibn Gabirol having borrowed the theme of love from the Sufis. We will speak of the Arabic poems later. First we turn to the poems by Ibn Gabirol cited 
by Levin, analyzing just one of these examples in order to demonstrate the method of comparison that I am proposing ${ }^{21}$ :

Hear, Lord of the world! Hear my praise; may my prayer be set like incense before You.

My heart loves you very much and is so unable to conceal it that it reveals its love in my speech.

At all times I reflect that tomorrow I return to You, for the beginning of my start was with You.

Lo, for Your sake, not mine, do I stand before You, and for the sake of Your glory, not for reward for my deed.

My soul has humbled itself before You when it came to clay, so that all my greatness has become no better than dust.

Like all rěsuyôt, this poem is definitely a prayer, and like most rěšyoôt its theme is the nature of prayer and the attitude of the worshiper as he stands before God. Though love is not the theme of the poem, verse 2 does speak of love ${ }^{22}$ and, as Levin correctly points out, refers to a convention of love poetry, the idea that the lover is unable to conceal his love because of its intensity.

But the way in which the lover unwillingly discloses his love is not through weeping, emaciation, sighs, depression, or any of the other signs of love so ably catalogued by Ibn azm; it is through words, presumably through the poem itself, or at least through the prayer to which the poem serves as a preamble. Ibn Gabirol often uses the rěsutut to explore and to explain the impulse to pray, and in several poems he explains this impulse as a welling up of love for God within himself, overflowing in words ${ }^{23}$. This form of the involuntary disclosure of love is not found in my Sufi corpus ${ }^{24}$. It is the joy of love that overflows in Ibn Gabirol, not the pain of love, as in the Sufis.

Nevertheless, Levin aligns Ibn Gabirol's rěšuyôt with a group of Sufi poems, and on the basis of this comparison he concludes that the short monorhymed Sufi poem was «nearly certainly the model

${ }^{21}$ Source: D. JARDEN, Sirê ha-qodeš ... Gabirôl, II, p. 465. The meaning of the last verse is most uncertain.

22 The Hebrew heseq was used as the equivalent of 'isq in Arabic, because of the similarity of the root letters.

${ }^{23}$ For more on this subject, see R. P. ScheinduIn, The Gazelle

${ }^{24}$ Though it is found, indirectly, in the Maŷnūn-Laylà tradition. 
for imitation (dëgam ha-hiqqûy) that Ibn Gabirol had in mind when he came to devise his innovative liturgical poems". If the comparison were apt, the conclusion would seem inescapable. All five of the Arabic poems cited by Levin are customarily attributed to Rābica al-cAdawiyya. According to the usual account, Rābica was active in the second half of the eighth century (she died in 185/801); as one of the earliest Muslim religious figures to bring the love of God into the circle of ideas of Islamic piety, she became a seminal figure of early Sufism. It is commonly said that she also originated the Sufi love poem, or at least that she was one of the first Sufis to compose religious love poetry; eleven poems are attributed to her ${ }^{25}$. Here is one of the examples of Rābica's poetry quoted by Levin ${ }^{26}$ :

O my joy, my desire, my support, and my friend, my help, and my desire.

You are my heart's breath, you are my hope, you are my intimate, and longing for you is my food.

It is You because of whom-O my life, my friendI have been scattered in the wide world.

How many boons have appeared, how much do I owe to You of gifts and benefits and aid.

Your love now is my desire and my pleasure, clarity to thirsty eye of my heart.

As long as I live I will never leave You, for you are firmly established in my heart.

If you are pleased with me, then I-O heart's desiremy happiness has appeared.

This poem and the others like it, though differing in significant respects from the rěsuyôt of Ibn Gabirol, also resembles them in important ways. For one thing, it is a prayer: the address to God is not merely a formality, but is of the poem's essence, providing the frame for an outpouring of simple, almost artless expressions of awe and devotion. It resembles the rěsuyôt in form and tone, for these too are short poems in plain diction that suggest a mood of intimacy

${ }^{25}$ This statistic is my own reckoning. All the known sources on Rābica are

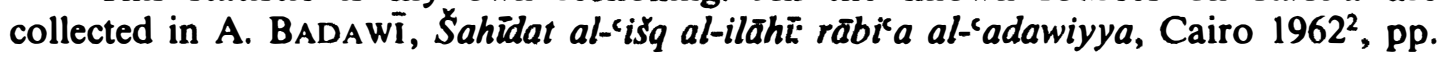
107-187. On these sources, see note 30 , below.

${ }^{26}$ Quoted in I. Levin, Ha-sód, p. 120 (my translation differs in some details from Levin's Hebrew translation); A. BADAwī, Sahidat, pp. 24-29; M. SMITH, Rābica the Mystic and Her Fellow Saints in Islam, Cambridge 1984², p. 28. 
by addressing God directly throughout with frequent repetitions of the pronouns of first and second person. It shares with the rěsût the attitude that the love of God is sustaining to the speaker, rather than being a cause of pain and sorrow. Especially its opening verse,

$y \bar{a}$ surūrī wa-munyatī wa-'imādi

wa-anisī wa-'uddatī wa-murādì

recalls in its rhythm such lines by Ibn Gabirol as,

mĕhôz hefsî̀ wĕ-șûr mahsî wĕ-kôsî

mênat helqî wĕ-gôralî wĕ-heblî̀

Although a note of anxiety can be detected in Rābica's poem, as noted by Badawi, there is in it also an undeniable warmth and security in the contemplation of the speaker's feelings that may be found in Ibn Gabirol's rěšuyôt as well.

But where was this mood when we were speaking of the love poems in the corpus of early Sufi poetry? Precisely what is lacking in that corpus is this warmth, this security, this sense that the speaker is sustained by love of God; rather, the prevailing tone is anxiety and pain. It seems almost as if my whole corpus stands on one side, and the eleven poems attributed to Rābica on the other across a great emotional divide, and that if Ibn Gabirol was influenced by any Sufi love poetry it could only have been by these eleven poems rather than by the more than two hundred in the corpus.

At this point it becomes necessary to examine the attribution of poems to Rābica. Levin is aware that these attributions are uncertain, for he begins his discussion of the examples taken from her work by saying that even if not all poems attributed to her are authentic, they "faithfully represent the style and spirit of her circle" ${ }^{27}$. But the problem cannot be so cavalierly dismissed. If we merely assume that the poems attributed to Rābica are typical of her circle, we ourselves are arguing in a circle. And the sources on early Sufism do not provide any confirmation that the eleven poems do represent the style and spirit of her circle. If we could be sure that the poems attributed to Rābica were roughly contemporaneous with her, it would not matter for our purposes whether they were written by her

${ }^{27}$ I. LEvin, Ha-sôd, pp. 125-126 (my translation). 
or by someone else. But of the eleven poems generally attributed to Rābica, only one, the famous "two-loves poem", actually occurs in sources that definitely predate Ibn Gabirol. All the others occur only in later sources ${ }^{28}$.

The earliest sources on Sufism present other problems in connection with Rābica. Some surprisingly do not mention her at all ${ }^{29}$. Others tell of another Rābica (or Rāyiya), the wife of Ahmad b. alHarawi; her personality is suspiciously like that of our Rābica, yet different enough to pose the question of just how many Rābicas there were and which stories belong to which? There are even different traditions concerning her most famous poem. One of the earliest sources, Kalabādî, quotes it anonymously ${ }^{30}$. The $Q \bar{u} t$ al$q u l \bar{b} b$ and the sources dependent on it ${ }^{31}$ attribute it explicitly to her on the authority of Sufyān al-Tawrì and others. But Abū Nucaym al-Işfahānì (who does not devote a chapter to Rābica) quotes it as

${ }^{28}$ Uhibbuka hubbaini hubba-l-hawà is translated in M. SMITH, Räbica, p. 102 and in her article, "Rābica al-'Adawiya", Encyclopaedia of Islam, Leiden 1913-1942, III, 1090; R. A. Nicholson, A Literary History of the Arabs, Cambridge 1956², p. 234; M. Lings, "Mystical Poetry", p. 239; its sources are discussed below. As for Rābi‘a's other poems: Only three other poems attributed to her are longer poems (six to seven verses), and all these occur only in Ibn Hurayfĩs (d. 801/1398), Yāfi $\mathfrak{i}$ (d. 768/1367), and a manuscript work by one Ibn Gānim al-Maqdisì (d. 768/1279). The other seven poems attributed to her are all short epigrams of two to three verses. The two-liners appear in al-Sarrāŷ al-Qāri’ (d. 1106); Ibn Ŷawzī (d. 597/1200); Ibn Ḥurayfîs; a commentary on Gazzālī's Ihy $\bar{a}^{\prime}$ by al-Zabìdī (d. 1167/1733); and a manuscript work by one 'Abd al-Ra'ūf al-Manāwì whom I cannot identify. The three-liner occurs in Ibn Gānim al-Maqdisî. Thus not one of these poems except Uhibbuka occurs in a source predating Ibn Gabirol. Rābica's poetic production at best was not very substantial, and poetry does not seem to have been an important part of her legend, at least not in the early centuries of Sufism. (Much of the source material in this note derives from Badawì, Sahidat al-`isq, with corrections derived from Brockelman). Professor Sidney Griffith called my attention to an excellent article by J. BALDICK, entitled "The Legend of Rābica of Başra: Christian Antecedents. Muslim Counterparts", Religion 20 (1990) 233-247, in which the Rābica legend is analyzed typologically. See also J. BALDICK's book Mystical Islam: An Introduction to Sufism, New York London 1989, pp. 28-29. Professor G. J. van Gelder has proposed, quite convincingly, that the poem under discussion was originally a secular love poem by a poet named $\bar{A}$ dam ibn 'Abd al-'Aziz. I wish to thank Prof. van Gelder to provide me with a copy of his unpublished paper "Rabi'a's Poem on the Two Kinds of Love: A Mystification?".

${ }^{29}$ Neither Sulamī nor Abū Nu`aym al-Işfahānī devotes a chapter to her. Sarrāŷy mentions her only once, as only one in a long list of miracle-workers.

${ }^{30}$ Ta'arruf, p. 80.

${ }^{31}$ Gazzali quotes it in her name in Ihyä culümi-l-dīn, edited by A. BaDAwi TABĀNA, Cairo n.d., IV, p. 302. 
having been recited by a mysterious woman who appeared to Dū-lNūn al-Mișrī in the "wilderness of the Israelites", while Zabìdī's commentary on Gazzālì's I $h y \bar{a}^{\prime}$ (eighteenth century) has another version of this story, in which the mysterious woman appears to Dū-l-Nūn by the sea shore. I have not explored the Rābica tradition beyond this point; but what I have just reported is enough to suggest that her figure is at least partly built up of Sufi folklore, and that the poetry attributed to her must be treated with greatest suspicion, not only as to who composed it, but, more importantly, when and in what circle it was composed. The research does not yet seem to have been done that would demonstrate when the Rābicalegend arose, and at what point which poems came to be attributed to her.

Thus the only poem attributed to Rābica in a Sufi treatise that was composed early enough to have been available to Ibn Gabirol is the "two-loves" poem, and even that is suspect. Furthermore, it has very little in common with Ibn Gabirol's rěšuyôt, except for the idea of love of God in general. Even if Ibn Gabirol knew this one poem, it seems unlikely that he could have had known the Rābicalegend as a whole or that the one poem could have inspired him to create the new rëšût. This chronological argument is not watertight, for many treatises and Sufi traditions may have existed in Ibn Gabirol's time that are completely unknown to us. But neither is it a weak argument, for there are plenty of sources predating Ibn Gabirol that could have cited poems by Rābica had they known them.

The poems attributed to Rābica have in common with Ibn Gabirol's rěšuyôt the theme of love of God and the tone of intimacy described above. But love of God is too general an idea to be seen in and of itself as the link between the two bodies of poetry. More impressive is the similarity in the poems' tone, the literary reflection of a religious mood of serenity that is quite uncharacteristic of early Sufi poetry. I gladly concede the similarity between Ibn Gabirol's poems and those attributed to Rābica, but I do not think that the religious experience expressed in these poems is characteristic of the Sufi poetry of the eighth to the tenth centuries. It therefore seems to me unlikely that these poems or poems like them could have been Ibn Gabirol's inspiration. 
V.

The agony of separation, the martyrdom of waiting passively for union with the beloved, the feeling of rejection and worthlessness experienced by the one who can do nothing to bring about the return of the absent one without whom the waiter's life has no meaning: this central experience of all the great Sufis, indeed of many of the world's great mystics, found its natural secular analogue in ' $u d \underline{r} \vec{i}$ poetry. In his personal poetry, Ibn Gabirol too deals with the agony of spritual isolation and passive waiting for illumination, but neither the experience for which he longs nor the literary form in which he expresses it is rooted in Sufism; likewise when in his religious poetry he turns to the predicament of the Jewish people, his imagery comes from other sources, primarily Jewish one as we have seen. Yet the ' $u d \underline{r} \vec{i}$ poetry that was such an excellent model for Sufi poetry was also potentially a model for poetry on the Jewish condition; for this was a people habituated to portraying itself as the abandoned beloved in the Song of Songs or the widowed wife in Lamentations, and to portraying God as an absent lover. It was only a matter of time before a Hebrew poet did come to make use of the Sufi model.

In a notoriously disturbing liturgical poem, Judah Halevi makes the leap ${ }^{32}$.

You have ever been the emcampment of love; my love encamped wherever You encamped.

The reproaches of my enemies for Your name's sake are sweet, let them alone to torment one whom You have tormented.

My foes learned your wrath, so I love them, for they pursue a corpse whom You have slain.

The day You hated me I loathed myself, for I will honor none whom You dispise.

Until Your anger pass, and You send again redemption to this Your inheritance which you once before redeemed.

The numerous elements in this poem that derive from Arabic love poetry have often been noted; all commentators have been disturbed by the extreme, almost perverse attitude of martyrdom

${ }^{32}$ Sources: D. JARDEN, Šîê ha-qodes lé-rabbî Yěhûdấ Halewî, Jerusalem 1978-1985, III, pp. 778-779; H. SCHIRMANN, Ha-sira ha-cibrit it, I, 467; for verse translation and discussion in R. P. Scheinduin, The Gazelle, poem 5. 
embraced by the poet. It was the inestimable contribution of Israel Levin to discover that this poem is not an original composition in which Halevi merely exploited the conventions of the Arabic love poetry but that it is actually-except for its last line-a translation of an Arabic poem ${ }^{33}$. The poet was Abū-l-Šşs, a contemporary of Abū Nuwās in the court of Hārūn al-Rašìd. Halevi's poem follows the Arabic quite closely, and in the same meter, quite a tour-deforce; by adding the last line, Halevi made explicit the connection between the attitude of the beloved and the proper attitude of Israel toward her sufferings ${ }^{34}$.

Levin did not try to trace the channels through which Abū-l-Šșis poem reached Halevi. The question might not even seem a fruitful one, for the poem was quite well known and widely quoted in adab works. Abū-l-Šș himself thought it his own best poem, and Abū Nuwās talked of plagiarizing it ${ }^{35}$.

But alongside the many sources within the official literary tradition, I have identified another set of sources that is more intriguing for us. Sulamî tells the following anecdote: Al-Murtaciš (d. 328/940), a Sufi master of Baghdad, was asked, "How can a slave achieve love [of God]?». He answered, "By associating with the friends of God and making enemies of His enemies». Then al-Murtaciš looked at one of his companions and said, «Recite the poem that you were reciting last night». In reply, the disciple recited two lines of the poem by Abū-l-Šș! ${ }^{36}$. Thus the Arabic source of Halevi's poem had been exploited for its religious meaning long before Halevi.

This is a typical case of a Sufi master using existing secular

${ }^{33}$ Y. Levin, "Biqqastî̀ 'et še'ahabâ nafș", Hasifrût 3 (1971) 116-119.

${ }^{34} \mathrm{H}$. SchirmanN quite properly pointed to the parallel passage in the Halevi's Kuzarî, I, 113 (see his $H a$-sîrâ ha- ibrît, I, 467). For further discussion, see R. P. SCHEINDLIN, The Gazelle.

${ }^{35}$ There is a good anecdote in which the two poets discuss this poem; one version is found in Ibn 'Abd Rabbihi's 'Iqd, Cairo 1316 A.H., III, p. 116; Halevi must have been familiar with this book, since it was a basic text for literary Andalusians. Other

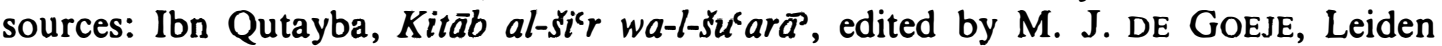
1904, p. 535; Abū-l-Faraŷ al-Işfahānī, Al-Agānī, Cairo 1320 A.H., XV, 105-06; Al-Jậ̉ al-Bagdādī, Ta'rīj bagdād, Cairo 1349/1931, v, p. 401; Al-Qālī, Ámālī, Būlāq, 1324 A.H., I, p. 221; Abū Tāmām, Dīwān al-Hamāsa, edited by G. W. FreYTAG, Bonn 1828, I, p. 602; Ibn Dā'ūd al-Işfahānī, Kitāb al-zahra, edited. by A. R. NYKL and I. TŨQĀN, Chicago 1932, p. 20. Most of these works could have been available to Halevi.

${ }^{36}$ Sulamî, Tabaqāt, pp. 359-360. 
poetry for the sake of some religious meaning that they could read into it. The theme that the 'abid must subject his will to that of God to the point of taking pleasure in his own harm is a familiar one in Sufism: Šbli among others composed verses of his own on this theme:

I take pleasure in my ruin through him, for

I take great pleasure in whatever gives my love pleasure.

It is also not rare in secular love poetry; Ibn Zaydūn, to take a poet closer to Halevi's time and place, has some lines about it ${ }^{37}$. There a-e parallels both in Hebrew secular and liturgical verse. But the passage from Sulami poses the comparatist an interesting question: Did Halevi get the idea on his own of turning the secular poem to liturgical use, or did he get it from the Sufi tradition?

There is nothing inherently improbable about Halevi getting the idea on his own. He had access to several of the works in which Abū-l-Šşs's poem is quoted; he did translate several poems from Arabic into Hebrew. But of the tens of thousands of Arabic love poems that had been written before and in his time and were available to him, does it not seem an amazing coincidence that he should have chosen just this poem, which had already been used for religious purposes by a Sufi master?

I have not been able to determine whether Sulamì's Tabaqāt was known in Spain in Halevi's time; but the poem can definitely be shown to have been used in Spain in a Sufi context. Little is known of Andalusian Sufism before the thirteenth century, but a few treatises are extant, including the Mahāsin al-maŷālis by Ibn al-cArif. This teacher was a contemporary of Halevi's (both died in 1141), and there is no difficulty whatever in assuming that a Jewish intellectual of Halevi's time could have had access to his works. In the section of Ibn al-cArif's treatise that deals with mahabba (one stage of love of God) he quotes as a prooftext the very verses that al-Murtaciš asked his disciple to repeat and that was adopted by Halevi! ${ }^{38}$.

37 Šiblī in his Dīwān, p. 93; Ibn Zaydūn, Dīwān, edited by A. 'ABD AL-'Az̄ì, Cairo 1957, pp. 166 and 181.

${ }^{38}$ The text was edited and translated by M. Asín Palacios, Paris 1933; see pp. 50 and 91 . Ibn al-'Arif quotes a secular poem or two for nearly every topic to which he devotes a chapter. Incidentally, a phrase from Abū-l-Siș' poem influenced the wording in another Sufi treatise, Kalābādīs Ta`arruf, p. 160. 
With the discovery of the passage in a contemporary Sufi work, it seems likely that Halevi knew Abū-l-Šșs poem in a Sufi context. Abū-l-Šsș's poem thus turns out to be a kind of missing link that establishes with fair certainty that at least Halevi was open to the influence of Sufism in some of his synagogue poetry. And precisely here, where there is an historical link between Arabic and Hebrew, there is also a thematic correspondence that goes beyond vague references to love. The religious impulse of certain Sufis and Halevi's view of Judaism were sufficiently close in this case that the very same poem could serve both.

There are other moments in Halevi's synagogue poetry that recall aspects of Sufi religiosity.

Hurt me more and I will love You more, for Your love is wonderful to me ${ }^{39}$.

Or,

People scorn me who do not realize

the shame I bear for Your name's glory is my pride.

While such lines do not have exact parallels in the Sufi poetry in my corpus, they do show their kinship with that poetry by combining the themes of love, suffering, and the lover's isolation. There is also in Halevi's religious verse a characteristic strain of pious passivity that seems almost a poetic embodiment of tawakkul, especially when compared with the more aggressive religious spirit of Ibn Gabirol ${ }^{40}$.

This is not the place to explore further here the degree of this kinship between Halevi's liturgical poetry and early Sufi poetry. I believe to have demonstrated that whatever influence Sufi poetry may have come to have on Jewish liturgy, it cannot account for the theme of love in the type of liturgical poetry pioneered by Ibn Gabirol in the eleventh century. The influence of Sufi poetry on the synagogue would thus first have been felt some time between Ibn

${ }^{39}$ D. JARDEN, Šîê ha-qodeš ... Halewî, III, pp. 763-764. Jarden points to a very similar line in Mutanabbì.

${ }^{40}$ For the contrast between these types of religiosity, see R. P. SCHEINDLIN, "Contrasting Religious Experience in the Short Liturgical Poems of Ibn Gabirol and Judah Halevi», Prooftexts 13 (1993) 141-162. 
Gabirol and Halevi, i.e., between approximately 1058 and $1085^{4}$. This comports well with the current opinion about the date of Bahya Ibn Paquda, whose Hidāya ila far $\bar{a}^{\prime} i d{ }^{\prime}$ al-qulüb represents the first evidence of the influence of Sufi ideas on Jewish thought. In the synagogue poetry of the generation between the two poets no traces of Sufism have yet turned up; I do not really expect that they will, for the two great poets of the intermediate period, Isaac Ibn Ghiyath and his disciple Moses Ibn Ezra, seem too much oriented toward philosophy to be fruitful ground for such a search.

VI.

We now turn to Levin's argument from zuhd poetry. From the start it is necessary to correct Levin's misconception that zuhd poetry is a forerunner of Sufi poetry. To say that the theme of zuhd is an important to Sufism is not to say that the poetry of zuhd is prominent in Sufism. My corpus of early Sufi poetry, as mentioned, is almost completely devoid of zuhd poetry. On reflection, the absence of this type of poetry is not all that surprising. The early Sufi masters used poetry primarily to teach their own ideas. But while asceticism and rejection of the world are important to Sufism, they are not peculiar to it; rather they are part of the overall religious heritage of Islam. Furthermore, when early Sufis used poetry in their preaching, one of the main effects they aimed for was paradox, as is especially evident in their use of secular love poetry. This rhetorical effect was not possible with zuhd poetry, which is simply what it is-versified preaching. Finally, zuhd poetry could well have been regarded by true religious virtuosi as somewhat tainted, for the most prominent zuhd poet was anything but a Sufi. Abū-l-'Atāhiya was not a pietist but a court poet who made a specialty of zuhd poetry. According to a famous anecdote, he had a confrontation with Abū Nuwās in which he drew the line between his territory and that of his rival, taking zuhd for himself and demanding that Abū Nuwās restrict himself to jamrīy $\bar{a} t$ and the like. The anecdote

${ }^{41}$ Ibn Gabirol's death date is contested, but the evidence favors 1058; see R. P. SCHeinduIn, "El poema de Ibn Gabirol y la fuente de los leones", Cuadernos de la Alhambra 29, [forthcoming]. Halevi is generally thought to have been born before 1075; I have allowed him to reach the age of ten before writing poetry, but it may have taken him longer. In any case, Ibn Gabirol and Halevi did not overlap. 
implies a certain cynicism toward the religious theme, as if Abū-l'Atāhiya's commitment to it was strictly a matter of business, and that the distribution could very well have gone the other way, with Abū Nuwās becoming the zuhd poet and Abū-l-'Atāhiya, the libertine. In fact, as we shall be discussing later, Abū Nuwās did write a few very interesting zuhdiya $\bar{a}{ }^{42}$. Zuhd poetry is thus not a forerunner of Sufi poetry but a different stream altogether ${ }^{43}$. Ibn Gabirol did borrow certain motifs from zuhd poetry, but these borrowings do not link him to Sufism.

But even more important than this technical argument is a more purely literary one. We can identify borrowings in Ibn Gabirol's poetry from zuhd poetry; but these borrowings do not establish a common spirit that links his inner world with that of the zuhd poet.

One of Ibn Gabirol's most fruitful innovations is the new tone of intimacy with which he invested the rěšut Golden Age's most distinctive purely poetic contribution to the Jewish liturgy. It is a tone that is not attested in previous Hebrew liturgical poetry, which always expresses itself in collective style. The only precedent for Ibn Gabirol's new tone is encountered through a leap backward over more than a millennium to the Psalms; only here do we find in early Hebrew literature the features that make the Golden Age rěšût so appealing: the constant play of first and second person, with the worshiper addressing God repeatedly and familiarly and speaking of his own personal experiences and needs (whether external and biographical or internal and spiritual) without reference to the community, as in all pre-Andalusian poetry of the synagogue.

Now if there was ever any poetry that lacked the intimacy of Ibn Gabirol's rěšuyot

On the assumption that one of the essential factors contributing to this tone of intimacy is direct address, and observing that Ibn Gabirol's poems most celebrated for this tone are those in which

42 The stories of Abū-l-'Atāhiya's stinginess and bad temper in the Agānī could almost be seen as parodies of the exempla of the Sufi masters in Sulami. See E. WAGNER, Abū Nuwās: Eine Studie zur arabischen Literatur der frühen Abbasidenzeit, Wiesbaden 1965, pp. 129-130; A. HAMORI, "Ascetic Poetry (Zuhdiyyāt)", in J. Ashtiany et al, (eds.), 'Abbasid Belles-Lettres, 265-274, 268; G. SCHOELER, "Bashshār b. Burd, Abū-l-‘Atāhiya, Abū Nuwās», ibid., 275-299, 287.

${ }^{43}$ See also R. JACOBI, "Arabische Dichtung», p. 46. 
the poet addresses either God or his own soul, let us make some comparisons. We start with Ibn Gabirol ${ }^{44}$ :

Lift up your eye, my soul, to your Rock, and think of your Creator in your youth.

Cry out to Him night and day, and sing ever with your song to His name.

Your portion and your lot on earth, your stronghold when you leave your flesh.

Has He not set for you a place of rest in His presence, has He not set your home beneath His throne?

Therefore I will bless the Lord, just as all souls bless Him.

The poet addresses his own soul, urging it to keep God constantly before itself. The word for «soul» (yẹhî̉ $\hat{a}$ ) is grammatically feminine; since each of the first four lines is addressed to her, all the verbs that apply to her have the second person feminine form. The rhyme syllable reinforces the address to the soul. It is rek, in which -ek is a pronominal suffix meaning "yours". The poem follows the Arabic rule of monorhyme with hemistich rhyme in the first verse, so that the first hemistich and the first four verses all end in "your Rock, your youth, your song, your flesh, your chamber». But in case we might still overlook the pronouns, the poet goes out of his way to focus our attention on them in verse 3 , with its internal rhymes:

měnat helqek wěkôsek ba-'adamâ

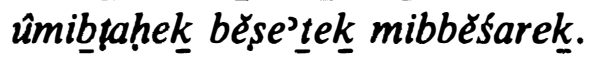

That the verse is meant to be climactic is indicated not only by the internal rhyme but also by its rhetorical structure, since, alone among the verses of the poem, it is built on antithetical balance. (The other verses are also parallel, but synonymous). It is also the middle verse of the poem. The five-fold address to the soul is thus circled in red, as it were, for our attention, and the soul is very much in the poem's foreground. Since the soul is advised to take action-to lift its eyes, to remember, to cry out, to sing-it almost seems to be personified.

Abū-l-‘Atāhiya has, as far as I know, no poem that is as com-

\footnotetext{
${ }^{44}$ D. JARDEN, Širê ha-qodeš ... Gabîrôl, II, pp. 333-334.
} 
pletely focused on the soul, though the expressions $y \bar{a}$ nafs or $y \bar{a}$ nafsi occur frequently in his dīwan. Here are some examples for comparison ${ }^{45}$ :

I examined my soul in my thoughts to see whether she would abandon what had deceived and abased her.

So I said to her, "O soul, what could I take from the world, even if I owned it all?

Is it anything but satisfaction after hunger, or desires that it is time for me to be weary of?

Or a period of time of which the days that have passed have left me but little?".

I see that you have a soul that wants you to honor it, but you cannot honor your soul except by humbling it.

In this example, Abū-l-cAtāhiya's address to the soul is set in a narrative frame. Thus, although the words $y \bar{a}$ nafs appear in verse 2, the pronoun embedded in the rhyme syllable that repeatedly brings us back to the soul is not second person but third. The narrative in verse 1 calls attention from the very beginning to the discontinuity between the speaker and the soul, whereas Ibn Gabirol calls attention to the self as speaker only in verse 5 , after the soul has been well established as the center of attention. Abū-l-‘Atāhiya's lacalla in verse 1 suggests doubt as to whether the soul will even heed his advice. But most telling is that after setting up the address to the soul as a near-personification that might have served to unify the poem, the poet drops her in the very next word following the

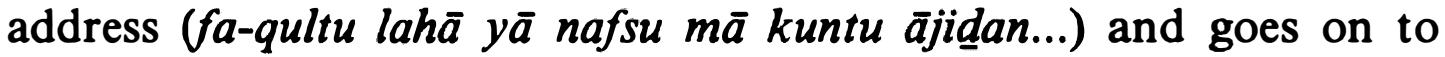
speak about himself, the nature of this material world, the brevity of his own life. By the end, he drops even the pretense of addressing the soul, turning to a second person masculine addressee and warning him of the need to keep his nafs under control ${ }^{46}$.

Another example ${ }^{47}$ :

${ }^{45}$ Abū-l-‘Atāhiya, Dīwān, edited by L. Cheikнo, Beirut 1887, p. 230.

46 The poet's address to himself in Arabic poetry, and the shifts between first, second, and third person in such addresses to the poet's self are the subjects of $\mathbf{G}$. J. VAN GelDER, "The Abstracted Self in Arabic Poetry", JAL 14 (1983-1984) 22-30. That article specifically excludes "those moralizing poems where the poet, although addressing himself, is in reality preaching to the audience or to mankind in general» (p. 26). Such cases are precisely the subject of the present article.

47 Abū-1-'Atãhiya, Dīwān, pp. 240-241. 
O my soul, it is but endurance for a few days: their pleasures are like confused dreams.

O my soul, why can I not get free of desiremy eye is quick to look up longingly to it.

$\mathrm{O}$ my soul, be at a distance from the world; keep it behind you, for good is ahead of me.

O my soul, treasure is only that which does you good in the grave when burial is my honor.

Time threatens in his changes; time takes apart and ties together.

This is the opening of a poem of seventeen verses. The first four are addressed to the soul. But the first two verses turn immediately from the apostrophe to speak of something in the third person. Verses 3 and 4 go on with a verb in the second person feminine singular; but verse 5 goes on with a completely new subject. The soul is now dropped. The next apostrophe does not occur until verse 14 , and it is to people in general: y $\bar{a}$ sākina l-duny $\bar{a}$. This is very typical of Abū-l-cAtāhiya: the opening address to the soul exists only so that the poet can address the soul about something other than herself: about dunyā, God's judgment, etc. Attention is quickly drawn away from the object of the address as the speaker gets more and more worked up.

As far as I can determine, only rarely does Abū-1-'Atāhiya make use of the second person feminine suffix and verb forms in the $q \bar{a} f i y a$ as a structural principle to reinforce the address to the soul and approach personification as we saw in Ibn Gabirol. But there are some examples; and the feminine grammatical forms can of course occur outside the rhyme syllable as well as within it. Here are two verses from the middle of a nine-verse poem ${ }^{48}$ :

O soul, repent before you will be unable to repent; and seek forgiveness for your sins of God, the pardoner of sins.

In these verses we recognize the tone of the male confessor or other father figure who lectures a wayward woman, a rather common

48 Ibid. p. 31. 
feature of these poems. These two lines to approach the feel of our example from Ibn Gabirol.

As a final example we have a poem in which the speaker keeps up the address to the soul for three verses before dropping away in the last two ${ }^{49}$ :

O soul! Where are my fathers, where is my father's father, and his father? Count-you have no father!-and reckon.

Count; for wherever I look I do not find any father between me and your father Adam!

Do you hope to be safe after they have gone?

Why do you not follow faithfully the path towards the face of the

All have died-embryo, suckling, weaned, mature, gray-haired.

So how long will I watch myself at play, when I see that fate, when it comes, does not play?

But even in the first three verses the tone is hardly intimate; the poem is a kind of harangue that could be addressed to anyone. In fact, such versified sermons make up a large part of Abū-l-cAtāhiya's diw $\bar{a} n$. The only difference between them and this example is that they are addressed outward, while this one is addressed inward.

The upshot of all these examples is that in Abū-l-cAtāhiya the soul is a convenient addressee for the poet's message; but there is very little motion in the direction of the kind of near-personification that we saw in Ibn Gabirol. The soul is never developed into a character with an imaginary personality. We might have expected her to be portrayed far more negatively, perhaps as a temptress that leads man astray, an image that does occur in contemporary Sufi writing ${ }^{50}$. But in Abū-l-cAtāhiya that role is reserved for dunyā, which is portrayed as actively wicked. The soul is at worst merely heedless, lazy, and unreflecting, just like members of a congregation listening to a sermon. Like the individual person for which it stands it must confront the thought of the last judgment as described in the Quran and in the Islamic tradition. Abū-l-'Atāhiya's soul is

49 Ibid. p. 23.

so Al-Muhāsibì, Kitāb bad’u man anāba ilā-l-lāhi 'azza wa-ŷalla, edited by $\mathrm{H}$. RITTER, Glückstadt 1935; Sulamī, Ŷawāmic adab al-sūfiyya and 'Uyūb al-nafs wamudāwātuhā, edited by E. KoHLBERG, Jerusalem 1979, pp. 70-107. 
merely a substitute for the poet's self, one of the many imaginary addressees of his versified sermons ${ }^{51}$.

Ibn Gabirol can never be as neutral toward the soul as can Abū1-cAtāhiya because the soul occupies a much more prominent place in his outlook on the nature of man. For him, the soul is part of a Neoplatonic scheme, a character in an elaborate myth of the nature of man and his relationship to God. For Ibn Gabirol, nefes, the Hebrew cognate of nafs, never stands for the lower instincts in man, and only rarely is it used neutrally to mean "self". Like its synonyms yẹhî́â and něšamâ, it stands for the higher or rational soul, emanated from God, divine in substance, and temporarily caged in a body. Its natural tendency is upward, toward union with its divine source. It can be diverted from that upward tendency by temporal things, but it can also be set back on its course by admonition, precisely because that course is natural to it. Thus Ibn Gabirol can encourage the soul, as in the poem quoted at the beginning, by reminding her than God is her portion in the world as well as her stronghold after death, and that God has provided her a resting place under His throne. Being amenable to correction, Ibn Gabirol's soul is a more human-like, more sympathetic being, and this partly accounts for the greater degree of personification we feel in his poems.

Ibn Gabirol does sometimes take a harsh tone in addressing the soul. Here are a few lines from a lengthy and stern tôkehâ, a poem of rebuke to the soul ${ }^{52}$ :

Return to your resting place, my soul! For God has treated you kindly ${ }^{53}$.

Did He not breathe you out of the breath of His mouth, and stretch you out from foot to head?

And with a little of His tremendous might $\mathrm{He}$ established you, and taught you a little of His great wisdom.

He taught you to explore the sciences, and gave you wisdom to know deep thoughts.

He surrounded you with wisdom and understanding

${ }^{51}$ This feature of moralizing poetry is distinguished from the poet's true address to himself in G. J. VAN GELDER, "The Abstracted Self", p. 26. On the "tyranny of the false 'I'", see J. STETkevyCH, "The Arabic Lyrical Phenomenon in Context", JAL 6 (1975) 57-77.

52 D. JARDEN, Sîrê ha-qodes ... Gabîról, II, pp. 543-545.

${ }^{53}$ The poem begins with a verbatim quotation from Psalm 116:7. 
and led you on the true path.

But you went astray from your Rock

and threw off His yoke from your neck.

You despised your intellect, you drew into your folly the sober,

You rejected your wisdom, you made wickedness your goal,

You stripped off the garments of love, and dressed instead in tattered rags.

You put out the light of your sun, you threw off the crown of your head.

You plotted evil every day, and hedged your path with thorns.

You pastured sin in herds, and heaped up deceit in piles.

You ruined your lovely beauty and hurt yourself, and went after vanity-and became vanity.

Therefore listen, girl, observe, and give your ear; open your eyes that you may escape the trap.

Stay away from sin, before it becomes too strong; keep far from evil before it ferments.

Fight your evil impulse with the sword of Torah, and return to your creator with a pure mind.

Repent thoroughly for acts of lust [Heb. zîmmâ]; set the sickle against the corn of your sin.

The language is harsh, and much of it does recall the rebukes of Abū-l-'Atāhiya. But the speaker never fails to recall the higher source of the soul or to challenge it to live up to its potential. And when he says, "Therefore, listen, girl, observe, and give your ear", he sounds as if he is admonishing a willful daughter rather than cursing a harlot. Whatever details of imagery Ibn Gabirol may have derived from Abū-l-'Atāhiya's world, the poems themselves are utterly different in spirit.

But the difference is not accounted for by the two poets' different religious affiliations. Most of the doctrinal content of Abū-l'Atāhiya's poetry would be perfectly acceptable to a Jew, and Hebrew poets did compose ordinary zuhdiyāt in Hebrew. The diffe- 
rence lies rather in the two poets' different attitudes toward the soul; it is this difference that dictated a different literary style.

Our comparison of the address to the soul in Ibn Gabirol to the address to the soul in Abū-l-'Atāhiya may be taken as a model for the whole question of Arabic influences on Ibn Gabirol. Levin is doubtless right that certain words, phrases, and images from Arabic and Islamic literature were adopted by Ibn Gabirol. But the bare philological fact that such borrowings exist is relatively trivial for literary history, for we already know that Hebrew poets were influenced by Arabic. We want to know the extent of the cultural dependence; we want to know how similar were the attitudes and sensibilities of Muslims and Jews. We cannot answer the deep literary and religious question by citing surface parallels. To gauge the extent to which acknowledged borrowings reflect a real intellectual kinship we must consider the tone and attitudes of the poem as a whole, as I have tried to do with the examples cited. Here, tone can be relatively easily defined and correlated with known intellectual positions. By this criterion, Ibn Gabirol seems quite far removed from zuhd, at least from the zuhd poetry of Abū-l-'Atāhiya. And to try to connect him with Sufism is even more far-fetched.

VII.

So where did Ibn Gabirol derive the peculiar intimacy of his rěšuyôt if not from zuhd poetry? Is it entirely his own invention? Are there models in Arabic?

Though it is customary to say that Arabic does not have a poetry dealing with the inner life of religion, and though there is no generally recognized poetic genre associated with religious themes except $z u h d$, it is nevertheless possible to compile a sizable collection of very touching Arabic prayers couched in poetic form. Such prayers turn up in several types of Arabic sources.

One source is my corpus of early Sufi texts, though this source is not as abundant in prayers as might be assumed. The bulk of the poems in this corpus are either expressions of the religious feelings of the ecstatic speaker couched in personal language (which I call religious fajr), or theoretical statements about what it means or what it is like to be an ecstatic. There are some prayers, and also there are some verses couched in the form of prayers that are 
included in the poems of personal ecstatic experience. In both kinds of prayers we find phrases that recall the Hebrew rěšuyôt of Ibn Gabirol or of other poets. Thus Junaid's fa-laisa lī min siwāka hazzun («apart from You I have no portion») corresponds to Halevi's $w \check{e}$-hûs helqî lébad mikkol camalî ( $\mathrm{He}$ alone is my portion of all my labor») ${ }^{54}$. Samnūn's wa-agit mā dāma bï ramaqun ("Save me while a bit of life remains") corresponds to Ibn Gabirol's 'ôdĕka bě $\hat{o} \underline{d}$ tihyeh / nišmat 'elôah bî̀ ${ }^{5 s}$. Yaḥyà Ibn Mucāḍ's rạ̣itu bisayyidī 'iwadan wa-'unsan / mina-l-ashya ${ }^{\prime} i$ lā abgi siwāhu ("I am satisfied with my Lord as replacement and companionship; as for things, I desire none but Him») corresponds to Halevi's lir'ôt pěnê malkî mĕgamatî léba see the face of my Lord; I fear none other, [none other] do I revere") ${ }^{56}$. But on the whole these apparent echoes do not add up to an obvious relationship between the two literatures.

Within the body of early Sufi poetry the poems of Hallāy represent a special case ${ }^{57}$. His identification with God is far more extreme than anything we can find in Golden Age Hebrew poetry; but it allows him to build paradoxes that occasionally recall those of Ibn Gabirol's rěšuyôt. Compare Ibn Gabirol's měrômôt lo' yěk̂îlûka

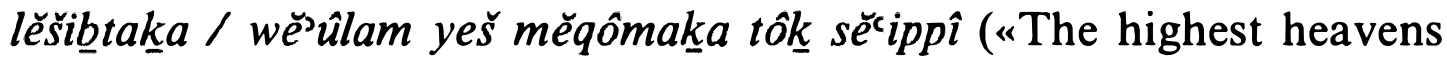
cannot contain You to dwell, and yet You have Your place in my thoughts") with Hallāŷ's makānuka fi qalbi huwa-l-qalbu kulluhu ("Your place in my heart is my entire heart») ${ }^{s 8}$. Further, Hallāŷ's way of playing the first person speaker against the second person God is a device typical of Ibn Gabirol and his followers ${ }^{59}$. In both poets it serves to highlight the common aspects of God and man,

54 Ŷunayd, in Abū Nu'aym al-Işfahānī, Hilyat, X, p. 284; Halevi, in D. JARdeN, Sî̀rê ha-qodeš ... Halewî, III p. 763.

ss Samnūn, in Sulamī, Tabaqãt, p. 190; Ibn Gabirol, in D. JARDEN, Šîrê ha-qodeš ... gabîrôl, I, p. 79.

${ }^{56}$ Yahyyà Ibn Mu‘ād, in Işfahānī, Hilyat, X, p. 62; Halevi, in H. SCHIRManN, Hasiria ha-'ibrît, I, p. 516.

${ }^{57}$ We should actually speak of the poems attributed to Hallāŷ, because his socalled diwān has definitely grown over the centuries.

${ }^{58}$ Ibn Gabirol, in D. JARDEN, Šîrê ha-qodeš ... Gabîrôl, II, pp. 461-462; Hallāŷ, in Dīwān al-Hallāŷ, edited by M. AL-Š́AYBİ, Baghdad 1984, p. 63.

59 This theme is the subject of a seminal article by A. MIRSKY, Mašma $a^{\complement} \hat{u t}$ he-harûz bě-sîrat sěfarad, Lëšônênû 33 (1968/1969) 150-195, reprinted in his Hapiyyut, Jerusalem 1990, pp. 315-386. 
though again Hallāŷ is more extreme than Ibn Gabirol. Ibn Gabirol could never have written Hiallāŷ's lines ${ }^{60}$ :

I am amazed at You and at me, $\mathrm{O}$ desire of the desirer!

You brought me so near to You that I think that You are I.

But his conviction of the divine character of the soul leads him to compare it explicitly with God and to compose some rather striking paradoxes:

For You I long with a thirsty heart; I am like a poor man begging at $m y$ door and $m y$ threshold ${ }^{61}$.

But we do not need to seek out extreme cases. Even outside Sufi literature we can find verse-prayers scattered in adab works. As mentioned above, Abū Nuwās, the arch-libertine, has several; ironically, these poems are the ones Levin cites as the link between Ibn Gabirol and zuhd poetry. But they are not zuhd poems at all; they are simply prayers of an intimate type that are as far removed from zuhd in tone as are Ibn Gabirol's Hebrew rěsuyôt. Several such prayers are found in the dīwān of Abū-l-'Atāhiya; one is supposed to have been recited by him on his death bed ${ }^{62}$ :

My God, do not punish me, for I acknowledge that which I have done.

I have no device except my hope and Your forgiveness-if You forgive-and my reliance.

How many a slip have I made among men, while You are over me, master of abundance and grace.

When I think of my regret over them, I bite my fingers and crack my teeth.

People think well of me, but I am the worst of men, if You do not forgive me.

I went made with the beauty of the world, and wasted my life with desire for it.

Before me is a weighty prison,

${ }^{60}$ Abū-1-‘Atāhiya, Dīwān, p. 78.

${ }^{61}$ I have explicated this verse in R. P. Scheindin, The Gazelle, pp. 183-187, and, from a different perspective, in "Contrasting Religious Experience».

${ }^{62}$ Abū-l-‘Atāhiya, Dīwān, p. 263. 
as if I am being summoned to it-as if...

Had I been sincere in renouncing it

I would have turned the back of my shield to its people.

Though not cited by Levin, this poem is actually quite similar in tone to those rěšuyôt by Ibn Gabirol that are addressed to God. But because of its penitential theme, it recalls the opening lines of a verse-prayer by Isaac Ibn Mar Saul, a poem that in its tone is a precursor of the Gabirolian rěšut ${ }^{63}$ :

My God, do not judge me according to my sin, and do not mete out to me what my deeds deserve.

In your mercy treat me kindly that I may livedo not, $\mathrm{O}$ God, pay me what I deserve.

I lower my soul's pride before You, and in pain I tear my heart and not my clothes.

Sick at heart I stand before You, sad because of my sin, my great wickedness and folly.

Struck with gloom, not with wine, my step has nearly fallen off from Your path.

What shall I say? Where shall I turn for help on judgment day? Where shall I flee, who will be with me?

But it is not only in theme that Ibn Mar Shaul's poem resembles that of Abū-l-'Atāhiya. The Arabic and the Hebrew poems are identical in meter, similar in rhyme, and begin with nearly equivalent words: "My God, do not punish me" (Abū-l-cAtāhiya) and "My God, do not judge me» (Ibn Gabirol). If the first lines are read in succession the similarity in sound and rhythm is striking:

ilāhī lā tu'addibnī fa'innī / muqirrun bi-l-ladî qad kana minnī 'elôhai 'al tédinênî kěma'lî / wèal tamod 'elê hêeqî kěfo'lî

Abū-l-cAtāhiya's deathbed poem is not the only one I have encountered in my perusal of $a d a b$ works; in my notes a small subgenre of Arabic deathbed poems is gradually emerging.

Another penitential poem that is remarkably similar in rhythm and tone to these two is by Abū Ișhāq al-Ilbirī, the qădq $\bar{i}$ who wrote

${ }^{63}$ Isaac Ibn Mar Shaul, in H. SCHIRMANN, Ha-sira ha ha ibrît, I, pp. 50-52. 
an inflammatory poem that contributed to the anti-Jewish riot of 1066. His penitential poem begins ${ }^{64}$ :

ataituka rāŷiyan yā dêa-l-yalāli

fa-farrî̀ mā tarā min sum'i hāli

I come to You in hope, O Majestic One!

So dispel my bad condition that You see.

The Arabic poets who produced these verse-prayers were not writing as religious leaders or religious authorities; they could adopt the personal tone we find in Ibn Gabirol's rěsuyôt precisely because they did not intend to teach doctrine or to preach repentance or to serve any public function. Their truly private prayers were an easily available model for the very thing that was lacking in the Jewish liturgical tradition up to Ibn Gabirol's time, a literature that since the time of the Psalms had dealt exclusively with the needs of the worshiping community: an individual voice. In the rěšût, the prefatory prayer of the ancient precentors, Ibn Gabirol or one of his contemporaries found the one liturgical genre suitable for the introduction of such a voice into the structure of the traditional liturgy. He extended its use to new parts of the service, and, most importantly, he recast it in the spirit of these occasional Arabic versified prayers, thus creating a genre that was to become one of the distinctive contributions of al-Andalus to Jewish worship.

${ }^{64}$ Quoted in Maqqarī, Nafh al-tî̉ min gusn al-andalus al-ratīb, edited by I. 'ABBĀS, Beirut 1988, IV, p. 317, n. 2. 


\section{RESUMEN}

La influencia del sufismo no puede servir de explicación para las innovaciones de Ibn Gabirol en el área de la poesía litúrgica hebrea, y la presencia de temas de amor y ascetismo no la vincula al sufismo. Los supuestos paralelismo de la poesía sufi con Ibn Gabirol son posteriores. La actitud de Ibn Gabirol hacia el alma es diferente de la expresada por la poesía zuhdí, que a su vez no es parte de la las oraciones personales en los escritos de poetas árabes ajenos a la esfera del sufismo. Por otra parte, en algunos poetas hebreos posteriores se manifiesta la influencia de la poesía sufi; es razonable considerar que un poema litúrgico de Judá Haleví estuviera inspirado en una fuente sufi. Pero la poesía sufi no está en el origen de las innovaciones de Ibn Gabirol que puso los fundamentos para sus sucesores en alAndalus.

\section{SUMMARY}

The influence of Sufism cannot account for Ibn Gabirol's innovations in the sphere of Hebrew liturgical poetry, and the presence of themes of love and ascetism in his poetry does not link his poetry to Sufism. Supposed Sufi parallels to Ibn Gabirol's poems are shown to be later. Ibn Gabirol's attitude toward the soul is different from that of zuhd poetry, which anyway is not really a part of the Sufi tradition. The intimate tone of Ibn Gabirol's liturgical poetry is closer to that of the personal prayers found among the writings of Arab poets outside the sphere of Sufism. On the other hand, later Hebrew poets may have been influenced by Sufi poetry; a liturgical poem by Judah Halevi can plausibly be shown to have been inspired by a Sufi source. But Sufi poetry does not account for the new directions taken by Ibn Gabirol that laid the foundations for his successors in al-Andalus. 